\title{
The Impact of Labor Contract and Labor Union on Social Security Right
}

\author{
Changzhe Shuai, Weidong Wu \\ Jinan University, Guangzhou, China \\ Email: 422971430@qq.com
}

How to cite this paper: Shuai, C. Z., \& Wu, W. D. (2018). The Impact of Labor Contract and Labor Union on Social Security Right. Advances in Applied Sociology, 8, 306-318.

https://doi.org/10.4236/aasoci.2018.84017

Received: March 23, 2018

Accepted: April 20, 2018

Published: April 23, 2018

Copyright $\odot 2018$ by authors and Scientific Research Publishing Inc. This work is licensed under the Creative Commons Attribution International License (CC BY 4.0).

http://creativecommons.org/licenses/by/4.0/

(c) (i) Open Access

\begin{abstract}
Based on ten cities' workers data about the employment situation of the worker in 2010, the paper analyzes the influence of labor contract and labor union on social security rights by using binary logistic regression model. The study found that: 1) labor contract and labor union contribute to the acquisition of the workers' social security right, and the promotion of labor contract is greater than that of labor union; 2) the impact of labor contract and labor union on different types of social insurance is also different, which is more reflected in the unemployment insurance and basic medical insurance, while less reflected in the work injury insurance.
\end{abstract}

\section{Keywords}

Labor Contract, Labor Union, Social Security Right, Basic Endowment Insurance, Basic Medical Insurance, Work Injury Insurance, Unemployment Insurance

\section{Introduction}

The household registration system has a far-reaching impact in China and is also an important factor that has led to the large-scale emigrated labor in and floating population (Yang, 2011a). At present, the number of floating population in China has reached as many as 247 million. Migrant workers have made an important contribution to the urbanization and industrialization of our country. Most of them are engaged in work with high intensity, poor working condition and low wages. Therefore, it is common for them to be threatened by diseases and accidents (Wu \& Chen, 2011). In addition, informal employment has become more and more popular among migrants and urban residents (Kuruvilla, Lee, \& Gallagher, 2011). When they are unfairly treated, it will make the protection of workers' rights increasingly prominent, especially the rights of social se- 
curity. According to the 2016 China Statistical Yearbook, including unsettled cases in the previous period, there were a total of 661,577 labor dispute cases in 2015 , containing 158,002 cases of social security, accounting for $23.88 \%$ of the total number of cases. Moreover, social security is one of the important ways for them to avoid risks and obtain social protection. It is crucial for improving the welfare of workers and their families (Yang, 2011b). Therefore, the governors tried to ease the conflicts between employers and employees so that protecting workers' rights in social security from the perspective of improving legislation, just as the "Labor Contract Law of the People's Republic of China" implemented in 2008 and the "Law on Labor Contract Reform of the People's Republic of China" in 2013 Decision. It clarifies the rights and obligations of both parties to the labor contract. It is required that the labor contract should have the terms such as the term of contract, contents and place of work, working hours and rest days, labor remuneration, social insurance and labor protection, etc. And in the general provisions, it clearly points out that the views of labor unions must be taken into account when an enterprise formulating, modifying or deciding on labor remuneration, working hours, insurance benefits and other systems. So in real life, do labor contract and labor union really take effect on the social security right of workers? Are there any differences between the impact of labor contract and labor union on social security right? If there is, which influence is stronger in both? How about different kinds of social insurances? And what kind of advice will be taken? These are questions that need to be discussed.

\section{Literature Review}

There have been very fruitful in the research about the influence of "Labor Contract Law" on the rights of workers in our country, which arouses our attention and concern on the protection of workers' rights. We can find out that promulgation of the Labor Contract Law will significantly improve the rate of signing labor contract (Li \& Freeman, 2014), extend the duration of labor contract and increase the number of non-fixed-term labor contract, which making cautious decisions in the recruitment and dismissal of enterprises (Cheng \& Yang, 2010). At the same time it will improve the welfare of employees (Cui, Ge, \& Jing, 2013; $\mathrm{Xu}, \mathrm{Qu}, \& \mathrm{Du}, 2017)$ and social insurance coverage (Li \& Freeman, 2014). Contrasting to the past, the coverage of social insurance is still becoming larger and larger, but the speed grows lower and slower, particularly in migrant workers (Gallagher, Giles, Park, \& Wang, 2014). The academic community is also constantly thinking whether the promulgation of the Labor Contract Law will have a positive effect on workers or not. Chen \& Liu (2014), from the perspective of the disadvantaged groups, found that although the promulgation of the Contract Law raised the level of protection for disadvantaged groups such as female workers and disabled workers, it was at the cost of a significant income gap. This is in line with the conclusion, drawn by Heckman \& Pages (2000), that labor protection enlarges the social income disparity in Latin American countries. And in OECD countries such stringent labor protection increases labor costs, 
which can lead to higher levels of structural unemployment (Scarpetta, 1998). Under the binary labor market in China, although the Labor Contract Law is beneficial to knowledge workers, it is negative for physical workers and will cut down the earnings. To sum up, Labor Contract Law can improve the profit of the working-class employees, but it will make the employment opportunities shrink through reducing of physical positions of the enterprises (Tang \& Zhao, 2009). From this, we can see that there is much controversy between workers' rights and the Labor Contract Law of our country. However, it can drive constantly progressive.

Since China being a part of the World Trade Organization, workers have greater autonomy under the globalization of the economy and the liberalization of the market. At the same time China will be asked to comply with international labor standards, that is, the basic ILO standard on protecting the rights of workers. In order to resolve various labor problems in our country, it is constantly strengthening and pushing forward the establishment of labor union that can give full play to the supervision and inspection functions (Zou, 2013). Therefore, with the vigorous promotion both at home and abroad, the labor union has made great strides. However, since all labor unions in China are affiliated or attached to the government, they lack of a true collective bargaining mechanism, even the right to strike and the monopoly power of labor supply. So some scholars doubt whether the Chinese labor unions can truly represent and enhance the rights of workers (Metcalf \& Li, 2006). In this aspect, scholars make so many arguments from different perspectives. Compared with employees who are not members of labor union, employees who participate in the labor union can enjoy more health and safety benefits and higher wages and benefits (Chen \& Chan, 2004; Ge, 2007; Yang \& Yang, 2013), which can also shrink the income gap among them (Frandsen, 2010; Han \& Castater, 2016). In the labor relationship, participating labor union will increase the rate of signing labor contracts and remission labor conflicts ( $\mathrm{Lu}$, Tao, \& Wang, 2009). In order to reflect the impact of labor union on workers' right more comprehensively, Yao \& Zhong (2013) found that labor union is significantly related to hourly wage and pension, and are weakly related to monthly working hour when introducing a variety of control variables by using IFC and Peking University China Center for Economic Research (CCER) data which contain 1268 enterprises in 12 cities in China in the spring of 2006. At the same time, the labor union also promotes the signing of personal labor contract and raises the workers' welfare. Therefore, a large number of relevant empirical studies tell us that China's labor union can play its role in protecting the rights of workers.

From the existing research, scholars pay more attention to the legal system such as the "Labor Contract Law of the People's Republic of China" promulgated in 2008 and the "Decision on Amending the Labor Contract Law of the People's Republic of China" in 2013. At the same time, scholars are also concerned about the role of social organizations to protect workers' right. However, the three parties, the governments, social organizations and workers are less involved in the 
analysis and comparison under the same framework. The rights of workers include varieties of rights such as equal employment, choice of job, remuneration, rest and vacation, labor safety and health protection, social insurance and welfare, vocational skills training and filing of labor disputes. The scope is too wide to be discussed in limited space. In view of this, we put government, social organizations and workers into the same framework to conduct an analysis and comparison with ten cities' workers data about the employment situation of the laborer in 2010 and binary logistics regression model. We hope to reveal more important factors in the transformation of labor relations in China, and to provide empirical references and policy implications for resolving labor conflicts, maintaining the stability of labor relations and protecting workers' right.

\section{Research Design}

\subsection{Model Construction}

Qing \& Liu (2014) argue that the labor law clearly stipulates that the establishment of labor relations need workers to sign labor contracts. However, because of the degree of compliance, law enforcement and the difficulty of protecting workers' right, the signing rate of labor contract in practice is far from the legal requirements, that is to say, the signing rate of labor contract is highly correlated with the macro legal, economic and social environment, but not with the individual characteristics of the worker. That is, the labor contract is not the result of workers' endogenous choices. Similar to the signing of labor contract, being the membership of a union is related to external labor laws and regulations and enterprise characteristics, but less relevant to self-selection. Therefore, it is reasonable to treat the union as an exogenous variable. Therefore, this article also based on labor contract and labor union as a dummy variable into the regression equation.

However, the acquisition of workers' rights in social security can be interpreted as a dichotomy, that is, the dependent variable is a binary variable. The "Social Security Right for workers" is set as a dummy variable. The samples participating in social insurance have a value of " 1 " and the samples without social insurance have a value of " 0 ". Logistics model is a common tool to analyze this kind of problem, and its theoretical basis is binary choice theory. The model function is a probability distribution function; the specific formula is as follows:

$$
p_{i}=F\left(z_{i}\right)=F\left(\alpha+\beta X_{i}+\mu\right)=\frac{1}{1+e^{-z_{i}}}=\frac{1}{1+e^{-\left(\alpha+\beta X_{i}\right)}}
$$

where, $Z_{i}=\alpha+\beta X_{i}+\mu$, e represents the logarithm of natural right. The estimated formula is:

$$
\ln \frac{p_{i}}{1-p_{i}}=Z_{i}=\alpha+\beta X_{i}+\mu
$$

where, $p_{i}$ is the probability of obtaining social security right of workers, $\beta$ is the 
parameters to be estimated, $X_{\mathrm{i}}$ is explanatory variables vector, and $\mu$ is the error term.

Based on the binary logistics model regression method to examine the factors that affect the social security right of workers, and the core variables to be investigated for labor contract and labor union, the basic model is as follows:

$$
\sum_{i=1}^{4} \text { Choice }_{i}=\alpha+\beta_{1} L C+\beta_{2} L U+\sum_{j=1}^{n} \beta_{j} C V_{j}+\varepsilon
$$

where, the explanatory variable is whether workers participate in Social Insurance-Choice ( 1 for participation and 0 for no participation). We analyze the four main types of social insurance: basic endowment insurance, basic medical insurance, unemployment insurance and work injury insurance. $L C$ represents labor contract for independent variables; $L U$ represents labor union for independent variables; $C V$ stands for control variable; $\varepsilon$ is residual.

\subsection{Data Sources}

The data of this study come from the "Employee Employment Status Survey" database funded by the National Social Science Fund Project. The survey was conducted in 10 cities including Xiamen, Tianjin, Shenzhen, Shanghai, Nanjing, Changsha, Chengdu, Wenzhou, Mianyang and Changchun. In order to make the survey more representative; the selection of cities is based on the data of the city's GDP in 2009. The specific levels include: cities (Mianyang, Wenzhou \& Xiamen) with a value of 300 billion yuan and below, cities (Chengdu, Nanjing, Changsha \& Changchun) with 300 to 700 billion yuan (excluding 300 billion yuan and 700 billion yuan) and over 700 billion yuan (Shanghai, Shenzhen \& Tianjin).

In a specific city, we used multi-stage cluster sampling and random sampling method, in accordance with the "district-Street-Community-Workers" in the order of multi-stage cluster sampling. Firstly we selected all area samples from the administrative district of the survey city randomly. Then, street samples are randomly selected from the streets of the district samples and community samples are randomly selected from the community samples of the street samples. Finally the investigation of households in the community is conducted. At the same time, in order to improve the efficiency of the questionnaire, only after respondents meet the requirements of the questionnaire, we can continue the household survey. We sent a total of 2000 questionnaires, and receive 1813 valid questionnaires. The effective rate of the questionnaire is about $90.7 \%$.

\subsection{Variable Description}

In order to investigate the acquisition of social security right, we will take the basic endowment insurance, basic medical insurance, unemployment insurance and work injury insurance as dependent variables, that is, dependent variable are whether to participate in the basic endowment insurance, whether to participate in basic medical insurance, whether to participate in unemployment insurance 
and whether to participate in work injury insurance, and we set: yes $=1$, no $=0$. The core variables are labor contract and labor union, representing the governments and social organizations. During analyzing and comparing labor contract and labor union's influence on social security right, we must isolate the core independent variables, so other factors that may affect the acquisition of social security right must be controlled strictly. Those control variables include individual demographic characteristics (Registered residence, Age, Gender, Marital status), socio-economic characteristics of individuals (Education status, Enterprise ownership, Industry category). The selection and description of the indicators is in Table 1.

Table 1. Variable description.

\begin{tabular}{|c|c|c|c|c|c|c|}
\hline Variable & Definition & Sample size & Average & Standard deviation & Minimum & Maximum \\
\hline $\begin{array}{l}\text { Basic endowment } \\
\text { insurance }\end{array}$ & yes $=1$, no $=0$ & 1780 & 0.502 & 0.500 & 0 & 1 \\
\hline $\begin{array}{l}\text { Basic medical } \\
\text { insurance }\end{array}$ & yes $=1$, no $=0$ & 1780 & 0.693 & 0.461 & 0 & 1 \\
\hline $\begin{array}{l}\text { Unemployment } \\
\text { insurance }\end{array}$ & yes $=1$, no $=0$ & 1780 & 0.237 & 0.425 & 0 & 1 \\
\hline Work injury insurance & yes $=1$, no $=0$ & 1779 & 0.352 & 0.478 & 0 & 1 \\
\hline Labor contract & yes $=1$, no $=0$ & 1798 & 1.371 & 0.483 & 1 & 2 \\
\hline Labor union & yes $=1$, no $=0$ & 1791 & 1.847 & 0.360 & 1 & 2 \\
\hline Registered residence & $\begin{array}{l}\text { local rural household }=1 \text {, local urban } \\
\text { household }=2 \text {, foreign rural household }=3 \text {, } \\
\text { foreign urban household }=4\end{array}$ & 1800 & 2.619 & 0.973 & 1 & 4 \\
\hline Age & specific number & 1769 & 27.086 & 7.228 & 16 & 62 \\
\hline Gender & $\operatorname{man}=1$, woman $=0$ & 1800 & 1.397 & 0.489 & 1 & 2 \\
\hline Marital status & $\begin{array}{l}\text { unmarried }=1 \text {, married }=2 \text {, divorced }=3 \text {, } \\
\text { widowed }=4\end{array}$ & 1795 & 1.345 & 0.494 & 1 & 4 \\
\hline Education status & $\begin{array}{l}\text { primary school and below }=1 \text {, junior high } \\
\text { school }=2 \text {, high school }=3 \text {, college }=4 \text {, } \\
\text { undergraduate }=5 \text {, master } \\
\text { degree and above }=6\end{array}$ & 1800 & 3.433 & 1.067 & 1 & 6 \\
\hline Industry category & $\begin{array}{l}\text { processing and manufacturing }=1 \text {, construction } \\
\text { industry }=2 \text {, retail and wholesale business }=3 \text {, } \\
\text { tourism industry }=4 \text {, hotel catering and } \\
\text { entertainment industry }=5 \text {, financial industry = } \\
6 \text {, transportation and logistics }=7 \text {, } \\
\text { housekeeping services }=8 \text {, real estate } \\
\text { industry }=9 \text {, education and training }=10 \text {, IT } \\
\text { Equipment/Services/Software }=11 \text {, other }=12\end{array}$ & $=$ & 5.495 & 3.944 & 1 & 12 \\
\hline Enterprise ownership & $\begin{array}{l}\text { state-owned enterprises }=1 \text {, private enterprise } \\
=2 \text {, Hong Kong enterprises }=3 \text {, Taiwan-funded } \\
\text { enterprises }=4 \text {, Japanese companies }=5 \text {, } \\
\text { Korean-funded enterprises }=6 \text {, European and } \\
\text { American companies }=7 \text {, } \\
\text { Collective enterprises }=8 \text {, other }=9\end{array}$ & 1785 & 2.494 & 1.893 & 1 & 9 \\
\hline
\end{tabular}




\section{The Empirical Results}

The results of the binary regression analysis of the model are shown in Table 2 and Table 3, and the following results can be obtained:

First, the signing of labor contract helps worker to safeguard their right and promote the acquisition of the workers' social security right. Specifically, at a $1 \%$ level of significance, workers with labor contracts have a positive effect on the access to basic endowment insurance, basic medical insurance, unemployment insurance and work injury insurance, which are of high statistical significance. This shows that the signing of labor contract can really enhance and promote the acquisition of social security right for workers. This conclusion is the same as Li \& Freeman (2014) and $\mathrm{Xu}, \mathrm{Qu}, \& \mathrm{Du}$ (2017). At the practical division, this also reflects the fact that labor contracts do have legal force after the promulgation of the Labor Contract Law in 2008.

Table 2. Result.

\begin{tabular}{|c|c|c|c|c|c|c|}
\hline \multirow{2}{*}{ Explanatory variables } & \multicolumn{3}{|c|}{ Basic endowment insurance } & \multicolumn{3}{|c|}{ Basic medical insurance } \\
\hline & $\mathrm{B}$ & S. E. & $\operatorname{Exp}(B)$ & B & S. E. & $\operatorname{Exp}(B)$ \\
\hline Labor contract & $1.047^{\star * *}$ & 0.116 & 2.848 & $1.337^{\star * *}$ & 0.119 & 3.808 \\
\hline Labor union & $0.627^{* * *}$ & 0.169 & 1.872 & $0.354^{* *}$ & 0.168 & 1.425 \\
\hline \multicolumn{7}{|l|}{$\begin{array}{l}\text { Registered residence (Foreign urban } \\
\text { household as a reference group) }\end{array}$} \\
\hline local rural household & -0.353 & 0.184 & 0.702 & $0.316^{*}$ & 0.192 & 1.372 \\
\hline local urban household & 0.319 & 0.168 & 1.375 & $0.507^{\star * *}$ & 0.178 & 1.660 \\
\hline foreign rural household & $-0.474^{* * *}$ & 0.152 & 0.623 & -0.030 & 0.159 & 0.970 \\
\hline Gender (Women as a reference group) & -0.012 & 0.112 & 0.988 & -0.019 & 0.116 & 0.982 \\
\hline Age & $0.069^{* * *}$ & 0.011 & 1.071 & 0.012 & 0.011 & 1.012 \\
\hline Marital status & 0.201 & 0.148 & 1.223 & -0.015 & 0.153 & 0.985 \\
\hline \multicolumn{7}{|l|}{$\begin{array}{c}\text { Education status } \\
\text { (Master as a reference group) }\end{array}$} \\
\hline Primary school and below & -1.016 & 0.748 & 0.362 & -0.115 & 0.723 & 0.891 \\
\hline Junior high school & 0.004 & 0.576 & 1.004 & -0.368 & 0.610 & 0.692 \\
\hline High school & 0.566 & 0.566 & 1.761 & 0.019 & 0.602 & 1.019 \\
\hline College & 0.909 & 0.567 & 2.482 & 0.017 & 0.604 & 1.017 \\
\hline Undergraduate & 0.653 & 0.570 & 1.922 & 0.059 & 0.608 & 1.061 \\
\hline Industry category & -0.019 & 0.014 & 0.982 & $-0.029^{\star}$ & 0.014 & 0.971 \\
\hline Enterprise ownership & 0.029 & 0.029 & 1.029 & $-0.061^{\star}$ & 0.029 & 0.941 \\
\hline Model Chi-square & \multicolumn{2}{|c|}{$370.964^{* * *}$} & & \multicolumn{2}{|c|}{$177.856^{* * *}$} & \\
\hline$-2 \mathrm{LL}$ & 2017.411 & & & 1932.409 & & \\
\hline Constant & $-3.194^{\star \star \star}$ & 0.651 & 0.041 & -0.318 & 0.699 & 0.727 \\
\hline
\end{tabular}

Note: $1{ }^{* * *},{ }^{* *},{ }^{*}$ respectively indicate that the coefficient of variables passed $1 \%, 5 \%, 10 \%$ significance test; 2 ) Due to the limitation of article length, the data of categorical covariates and specific variables of Industry category and enterprise ownership in the table have been omitted and are not displayed. 
Table 3. Result.

\begin{tabular}{|c|c|c|c|c|c|c|}
\hline \multirow{2}{*}{ Explanatory variables } & \multicolumn{3}{|c|}{ Unemployment insurance } & \multicolumn{3}{|c|}{ Work injury insurance } \\
\hline & $\mathrm{B}$ & S. E. & $\operatorname{Exp}(B)$ & $\mathrm{B}$ & S. E. & $\operatorname{Exp}(B)$ \\
\hline Labor contract & $1.391^{* * *}$ & 0.164 & 4.018 & $0.952^{* * *}$ & 0.122 & 2.592 \\
\hline Labor union & $0.427^{\star * *}$ & 0.160 & 1.533 & $0.389^{* * *}$ & 0.147 & 1.475 \\
\hline \multicolumn{7}{|l|}{$\begin{array}{l}\text { Registered residence (Foreign urban } \\
\text { household as a reference group) }\end{array}$} \\
\hline local rural household & 0.203 & 0.220 & 1.224 & -0.071 & 0.189 & 0.932 \\
\hline local urban household & $0.640^{* * *}$ & 0.175 & 1.897 & 0.090 & 0.163 & 1.094 \\
\hline foreign rural household & -0.216 & 0.182 & 0.806 & 0.087 & 0.154 & 1.090 \\
\hline Gender (Women as a reference group) & 0.073 & 0.131 & 1.076 & 0.606 & 0.112 & 1.834 \\
\hline Age & $0.053^{* * *}$ & 0.012 & 1.055 & $0.019^{*}$ & 0.010 & 1.020 \\
\hline Marital status & 0.078 & 0.166 & 1.081 & -0.091 & 0.143 & 0.913 \\
\hline \multicolumn{7}{|l|}{$\begin{array}{c}\text { Education status } \\
\text { (Master as a reference group) }\end{array}$} \\
\hline Primary school and below & -0.402 & 1.124 & 0.669 & $1.266^{*}$ & 0.717 & 3.548 \\
\hline Junior high school & 0.332 & 0.814 & 1.393 & 0.799 & 0.612 & 2.224 \\
\hline High school & 1.159 & 0.793 & 3.187 & 0.722 & 0.602 & 2.058 \\
\hline College & $1.582^{\star *}$ & 0.792 & 4.865 & 0.643 & 0.603 & 1.902 \\
\hline Undergraduate & $1.669^{* *}$ & 0.794 & 5.306 & 0.684 & 0.606 & 1.981 \\
\hline Industry category & -0.007 & 0.016 & 0.993 & -0.036 & 0.014 & 0.965 \\
\hline Enterprise ownership & $-0.054^{\star}$ & 0.033 & 0.947 & -0.027 & 0.028 & 0.973 \\
\hline Model Chi-square & \multicolumn{2}{|c|}{$311.729 * * *$} & & \multicolumn{2}{|c|}{$151.933^{* * *}$} & \\
\hline$-2 \mathrm{LL}$ & 1588.398 & & & 2081.932 & & \\
\hline Constant & $-5.115^{\star * *}$ & 0.867 & 0.006 & $-2.594^{\star * *}$ & 0.668 & 0.075 \\
\hline
\end{tabular}

Note: the same Table 2.

Second, the participation of labor union helps to ease conflicts that cannot be solved in the construction and adjustment of individual labor relations, and promotes the acquisition of workers' social security right from the direction of collective labor rights. Specifically, workers participating in labor unions have a positive effect on the access to basic endowment insurance, unemployment insurance and work injury insurance at a $1 \%$ level of significance; Under $5 \%$ level of significance, it also have a positive effect on the access to basic medical insurance, which has a statistically significant significance. Compared with the massive loss of union members (An, 2002) and the unclear role of labor union (Bao, 2001) in the past, there is no doubt that the labor unions in China are constantly developing and emerging their power, and also answered question that Metcalf \& Li (2006) doubt whether Chinese labor unions can really represent and enhance the interests of workers.

Third, labor contract and labor union have different impacts on the acquisi- 
tion of social security right, and the promotion effect of labor contract on the acquisition of social security right is greater than that of labor union. On the whole, the odds ratio $(2.848,3.808,4.018,2.592$, respectively) that labor contract affect the right of workers in social security are higher than labor union's (1.872, $1.425,1.533,1.475$, respectively), which shows that the promotion effect of labor contract on social security right is greater than labor union. According to different levels of the subject of the equity, it can be divided into individual labor rights and collective labor rights. The former includes labor contract and other aspects, and the latter exercises power by the labor union (Chang, 2002). In fact, the construction and adjustment of individual labor relations cannot solve the labor-capital conflict and maintain the stability of labor relations. Therefore, the marketization of labor relations in our country needs to be transformed from individual labor relations to collective labor relations. This is not only the general trajectory of the adjustment and development of labor relations in market economy countries, but also a historical process of the structure and adjustment of labor relations (Chang, 2013). At the same time, the current labor policy is a set of workers' rights protection system based on the Labor Contract Law and considered the labor unions as the platform $(\mathrm{Xu}, \mathrm{Qu}, \& \mathrm{Du}, 2017)$. Therefore, labor contract's enhancement for the acquisition of social security right is stronger than labor union's. The conclusion is consistent with the current situation and the historical process.

Fourth, labor contract and labor union also have different influences on different types of social insurance. And it is mainly reflected in unemployment insurance and basic medical insurance, but less in basic endowment insurance and work injury insurance. Specifically, the impact of labor contract on basic endowment insurance is about 1.52 times that of labor union (both ratio of the odds ratios, similarly hereinafter). The impact of labor contract on basic medical insurance is about 2.67 times that of labor union. The impact of labor contract on unemployment insurance is about 2.62 times that of labor union. The impact of labor contract on work injury insurance is about 1.76 times that of labor union. The difference in the impact on the four types of social insurance are followed by $1.52,1.76,2.62,2.67$, which shows that there is the biggest difference between the impact of labor contract and labor union on basic medical insurance, followed by work injury insurance, unemployment insurance and basic endowment insurance. And the conclusion of basic endowment insurance and work injury insurance is more similar, while unemployment insurance and basic medical insurance are more similar.

From the perspective of the role of labor contract and labor union, this may be due to the fact that labor contract mainly involves the basic social insurance. On the other hand, labor union plays a complementary role in building a security system that is mutually supportive and mutually beneficial. It mainly includes life assistance, medical assistance, subsidized children's education, start-up loans, employment agencies, job training, policy advice and legal aid. According 
to the existing "Statistical Community on the Work Situation of labor unions and labor unions in 2012", it shows that funds are used for life assistance, medical assistance, subsidized children's education, start-up loans, employment agencies, job training, policy advice and legal aid respectively accounting for, $41.6 \%, 16.9 \%, 16.3 \%, 11.5 \%, 1.1 \%, 7.6 \%, 0.1 \%$ and $2.8 \%$. It can be clearly seen that labor union plays a larger role in providing unemployment assistance and medical assistance, which makes worker's demand on unemployment insurance and basic medical insurance lower than that on basic endowment insurance and work injury insurance. So the impact is more different in unemployment insurance and basic medical insurance, while the impact is little different in basic endowment insurance and work injury insurance.

\section{Conclusions and Policy Implications}

Based on ten cities' workers data about the employment situation of the worker in 2010, this paper takes the basic endowment insurance, basic medical insurance, unemployment insurance and work injury insurance as the representatives to study the influence of labor contract and labor union on the acquisition of the workers' social security right. Being divided into four groups according to the types of insurance, we use the binary logistics model regression analysis to compare the workers to participate in social insurance, and the results show that:

1) the signing of labor contract helps worker to safeguard their right and promote the acquisition of the workers' social security right; 2) the participation of labor union helps to ease conflicts that cannot be solved in the construction and adjustment of individual labor relations, and promotes the acquisition of workers' social security right from the direction of collective labor rights; 3) labor contract and labor union have different impacts on the acquisition of social security right, and the promotion effect of labor contract on the acquisition of social security right is greater than that of labor union; 4) labor contract and labor union also have different influences on different types of social insurance. And it is mainly reflected in unemployment insurance and basic medical insurance, but less in basic endowment insurance and work injury insurance

In order to effectively safeguard the rights of workers in social security, and combine with differences in the fact that labor contract and labor union have impact on various types of social insurance, this paper proposes the following policy implications:

Firstly, we must continue to perfect relevant laws and regulations, intensify the implementation of labor security and break the labor law environment of "re-enacting legislation and enforcing the law lightly". In particular, we must severely crack down on the violation of the new law that established legal labor relations, and increase supervision and punishment. Since the record, from $86.4 \%$ of the labor contract signing rate in 2011 to $90 \%$ of the labor contract signing rate in 2015, despite the continuous increase in the labor contract signing rate, incidents that infringe the rights and interests of employees often occur. 
The reason for this is not only the imperfections of the law, but the lack of execution of law enforcement officers and the lack of supervision over the entire labor relations system. Therefore, in the situation where there are laws to follow, all departments should strictly enforce the law and never tolerate infringement.

Secondly, in order to strengthen the formulation of supporting policies and systems related to labor union, we should not only give full play to the legal forces that maintain the labor relations between individuals and enterprises, but also increase the organizational strength of the bottom-up negotiation between employees and the enterprise. We also must separate the management and administrative departments of the labor union to form a social organization with strong binding force, and enhance the cultural connotation of labor unions through various online media propaganda means, which will make employees more sense of belonging, increase the density of labor unions, maintain the stability of the labor relations and contribute to the reform of the labor relations transition in our country.

Thirdly, it is necessary to establish a linkage mechanism between the labor contract and the labor union so that the two parties will spiral forward in constant revision and exploration. Especially in the influence of labor unions, due to the historical reasons for their development, we should pay more attention to the development of labor union and enhance their protection capabilities. At the same time, we also need to carry out targeted propaganda and help to employees according to different insurance types. And then we hope that labor contract have the same influence as labor union through our continuous promotion. Finally, the differences between different types of insurance are narrowed to effectively safeguard the rights of workers and maintain the balance of labor relations.

\section{References}

An, L. (2002). Several Problems Faced by Chinese Trade Unions in the WTO Background. Trade Unions' Tribune, 8, 1-4.

Bao, Z. (2001). The Role and Mission of Contemporary Chinese Trade Union Organizations: Some Analysis from the Perspective of Development Economics. Trade Unions' Tribune, No. 1, 1-3.

Chang, K. (2002). WTO, Labor Standards and Protection of Labor Rights. Social Sciences in China, No. 1, 126-134.

Chang, K. (2013). The Collectivization Transition of Labor Relations and the Perfection of Government Labor Policies. Social Sciences in China, No. 3, 91-108.

Chen, D., \& Liu, J. (2014). Is Labor Protection Contributing to Reducing the Relative Income Disparity of the Disadvantaged in Employment?-Taking the Implementation of the New Labor Contract Law as an Example. Finance \& Trade Economics, 35, 111-120.

Chen, M., \& Chan, A. (2004). Employee and Union Inputs into Occupational Health and Safety Measures in Chinese Factories. Social Science \& Medicine, 58, 1231-1245. https://doi.org/10.1016/S0277-9536(03)00315-0

Cheng, Y., \& Yang, L. (2010). The Impact of the Implementation of "Labor Contract 
Law" on the Human Resources Management of Chinese Enterprises: Based on the Viewpoint of Human Resources Managers. Economic Theory and Business Management, $V, 66-73$.

Cui, F., Ge, Y., \& Jing, F. (2013). The Effects of the Labor Contract Law on the Chinese Labor Market. Journal of Empirical Legal Studies, 10, 462-483.

https://doi.org/10.1111/jels.12016

Frandsen, B. (2010). Union Wage Setting and the Distribution of Employees' Earnings: Evidence from Certification Elections. Cambridge: Massachusetts Institute of Technology.

Gallagher, M., Giles, J., Park, A., \& Wang, M. (2014). China's 2008 Labor Contract Law: Implementation and Implications for China's Workers. Human Relations, 68, 197-235. https://doi.org/10.1177/0018726713509418

Ge, Y. (2007). What Do Unions Do in China? SSRN Electronic Journal. https://doi.org/10.2139/ssrn.1031084

Han, K., \& Castater, E. (2016). They May Not Have the Skills, but They Have the Desire: Why the Skill Composition of Trade Unions Matters for Wage Inequality. Research in Social Stratification and Mobility, 45, 1-12. https://doi.org/10.1016/j.rssm.2016.05.001

Heckman, J., \& Pages, C. (2000). The Cost of Job Security Regulation: Evidence from Latin American Labor Markets. Economía, 1, 109-144. https://doi.org/10.1353/eco.2000.0007

Kuruvilla, S., Lee, C. K., \& Gallagher, M. (2011). From Iron Rice Bowl to Informalization: Markets, Workers, and the State in a Changing China. Ithaca: Cornell University Press. https://doi.org/10.7591/cornell/9780801450242.001.0001

Li, X., \& Freeman, R. (2014). How Does China's New Labour Contract Law Affect Floating Workers? British Journal of Industrial Relations, 53, 711-735.

https://doi.org/10.1111/bjir.12056

Lu, Y., Tao, Z., \& Wang, Y. (2009). Union Effects on Performance and Employment Relations: Evidence from China. China Economic Review, 21, 202-210. https://doi.org/10.2139/ssrn.1495662

Metcalf, D., \& Li, J. (2006). Chinese Unions: An Alice in Wonderland. In Advances in Industrial \& Labor Relations (pp. 213-268). Bingley: Emerald Group Publishing Limited. https://doi.org/10.1016/S0742-6186(06)15005-2

Qing, S., \& Liu, M. (2014). Labor Contract and Trade Union's Protection of Rights and Interests-Based on the Empirical Analysis of CGSS2008. Sociological Review of China, 2, 57-70.

Scarpetta, S. (1998). Labor Market Reforms and Unemployment: Lessons from the Experience of the OECD Countries. https://doi.org/10.2139/ssrn.1817181

Tang, Y., \& Zhao, W. (2009). Dual Labor Market, Dismissal Protection and Labor Contract Law. Nankai Economic Studies, No. 1, 122-132.

Wu, Z., \& Chen, D. (2011). A Survey of the Research on the Social Security of Floating Population. Theory Journal, No. 1, 64-70.

$\mathrm{Xu}, \mathrm{L} ., \mathrm{Qu}, \mathrm{S} .$, \& Du, S. (2017). Labor Contract, Identity of Trade Unions, and Rights and Interests of Laborers-Verification Based on CGSS2013 Data. Collected Essays on Finance And Economics, No. 1, 3-11.

Yang, J. (2011a). Difference between Urban and Rural Areas and Internal and External Differences: Social Security Research for Floating Population. Population Research, No. 5, 8-25.

Yang, J., \& Yang, Q. (2013). Trade Unions, Political Connections and Wage Decisions: 
Analysis Based on Survey Data of Chinese Enterprises. World Economic Papers, No. 2, 36-49.

Yang, S. (2011b). On the Transfer of Rural Labor in China. PhD, The Party School of the Central Committee of the CPC.

Yao, Y., \& Zhong, N. (2013). Unions and Workers' Welfare in Chinese Firms. Journal of Labor Economics, 31, 633-667. https://doi.org/10.1086/669819

Zou, Q. (2013). The Status Quo and Development of China's Trade Union Legislation-From the Perspective of Comparative Legislation of China-US Trade Union. People’s Tribune, No. 32, 247-249. 